\title{
Effective Blended Learning of Microbiology using Interactive Web 2.0 Applications
}

\author{
Wan Zuhainis Saad \\ Department of Microbiology, Faculty of Biotechnology and Biomolecular Sciences, Universiti Putra Malaysia, \\ 43400 UPM Serdang, Selangor, Malaysia \\ zuhainis@upm.edu.my
}

\begin{abstract}
Free online Web 2.0 tools were used in the teaching and learning of Microbiology courses with blended learning approach. The innovation applied able to enhance engagement, collaboration, communication and meaningful learning among students and educators. The tools used have created excitement and developed critical thinking skills. Application of blended learning and flipped classroom showed positive impacts on the students, resulting in developing higher order thinking skill within an enjoyable learning environment. A survey on Microbiology students' perceptions on using the Web 2.0 tools in enhancing learning showed that students were inspired to explore more about microbes and their impact to the world when using the tools learned. Data from students interviewed had shown that learning Microbiology was more effective and enjoyable when using collaborative Web 2.0 tools. The tools were not only can be used in learning Microbiology courses but the students were able to apply the tools in learning other relevant courses. Thus, the approach used in this course offers a bright future to be implemented in any other courses regardless of background or subject and further grooming individuals to become independent lifelong learners.
\end{abstract}

Keywords: Web 2.0, Microbiology, Blended Learning, Flipped Classroom

\section{Introduction}

Integration of e-learning has facilitated students' learning activities through online delivery and face-to-face mode. Studies in Australia $[1,2]$ in the US $[3,4]$ and in the UK [5] have confirmed that the vast majority of the students have ready access to web-enabled laptop and own personal digital devices such as smartphones. They also use a wide range of digital features and web features such free online Web 2.0 tools in their everyday lives, for communication (emails, whatsapp, twitter, etc.). One of the major advantages of e-learning technologies is the expanded opportunities that they offer for when and where interactive learning takes place. Blended learning and flipped classroom are other education concepts that are able to benefit students in developing their higher order thinking skills and enhanced learning.

While students who were first introduced to the technology in generally gave us positive comments about the technology, those who actually spent more time on it were much less enthusiastic. Therefore, the students' habits and perceptions should be taken into considerations in integrating technology in education.

\section{Research Questions}

This study aims to address the following questions:

a. What are undergraduate microbiology students' perceptions on e-learning?

b. Did the learning activities enhance their learning in Microbiology course?

\section{Methodology}

The purposes of this study were to examine students' perception towards e-learning, to identify and factors that influence students' adoption or resistance of e-learning. Students who are more comfortable with technology in their everyday lives may more readily accept using technology in another context. The students' perception of using e-learning is influenced by different variables, including previous experiences of usage of computers [6]. The survey instrument incorporated open-ended questions regarding their experience in using Web 2.0 tools in their learning activities. We also studied the usage of e-learning strategies in the teaching and learning context. The questions sought to determine whether students perceived that they had used the e-learning tool effectively, benefited by the tools and motivation of using the tools. The survey form was prepared and published online using GoogleForm. The focus groups were undergraduate students of Bachelor of Science (Hons.) Microbiology program.

\section{Findings}

A total of 90 Microbiology students participated in this survey where 37 were undergraduate Year 1, 21 and 32 were respondents from Year 2 and 3, respectively. From the study, we found that, the students had experiences in using their laptop in everyday lives and $50 \%$ were involved in elearning activities. Almost $40 \%$ of the students used smartphone as their digital device to connect and involve in the e-learning activities as tabulated in Table 1.

Figure 1 shows the familiarity of the e-learning tools the students had used in their learning activities of Microbiology 
course. Over half of the students used the Web 2.0 tools in their daily lives as given in Fig. 2.

Table 1: Devices and frequency used in the e-learning activities.

\begin{tabular}{|c|c|c|}
\hline \multicolumn{2}{|c|}{} & Percentage (\%) \\
\hline \multirow{3}{*}{$\begin{array}{c}\text { Devices use for } \\
\text { e-learning } \\
\text { activities }\end{array}$} & Laptop & 78 \\
\cline { 2 - 3 } & Smartphone & 38 \\
\cline { 2 - 3 } & Tablet/iPad & 9 \\
\hline \multirow{2}{*}{$\begin{array}{c}\text { Frequency of } \\
\text { involvement in } \\
\text { e-learning } \\
\text { activities }\end{array}$} & Desktop PC & 6 \\
\cline { 2 - 3 } & Always & 50 \\
\cline { 2 - 3 } & Sometimes & 43 \\
\hline
\end{tabular}

Students were given tasks using Web 2.0 application such as E-portfolio, e-scrapbook, Brainstorming using mindmap and etc as described in Fig. 3. The students strongly agreed that making flashcards using Quizlet and mind mapping had enhanced their learning on the Microbiology course followed by reflective journal and one minute paper using Padlet. The tasks were given through series of blended learning and flipped classroom implemented in the course.

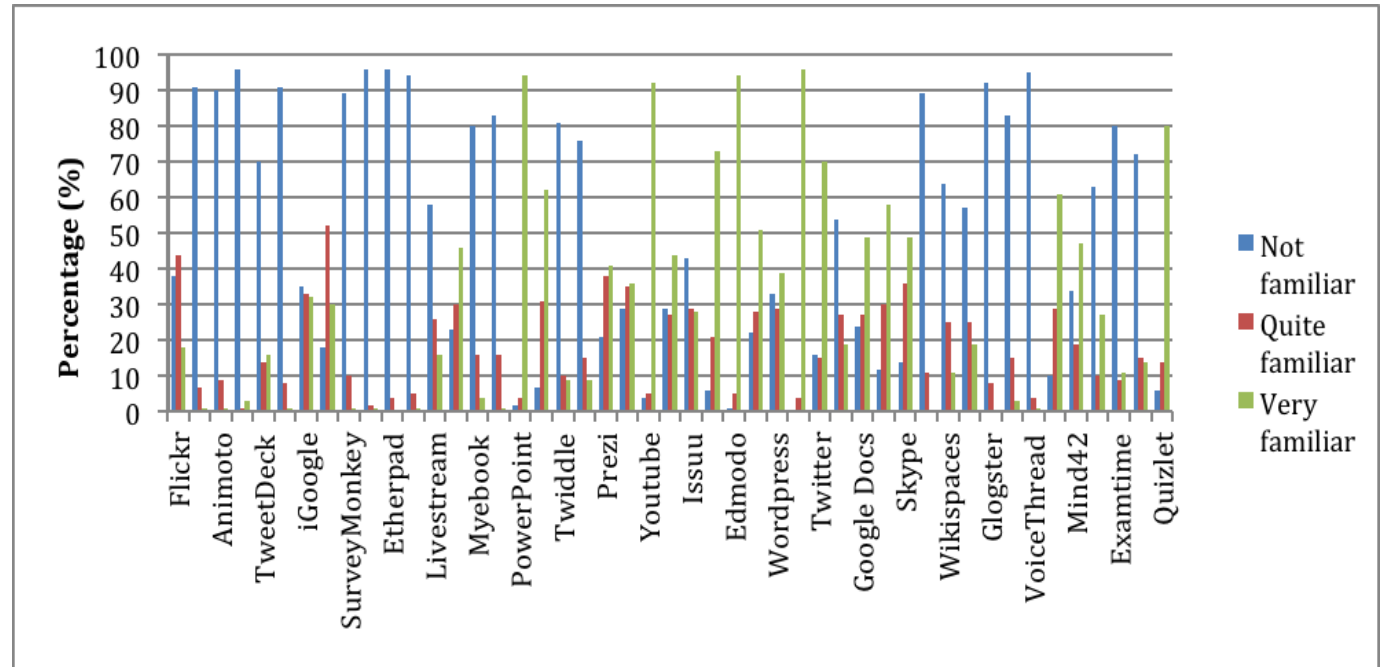

Fig. 1. Familiarity of e-learning tools that the students have used.

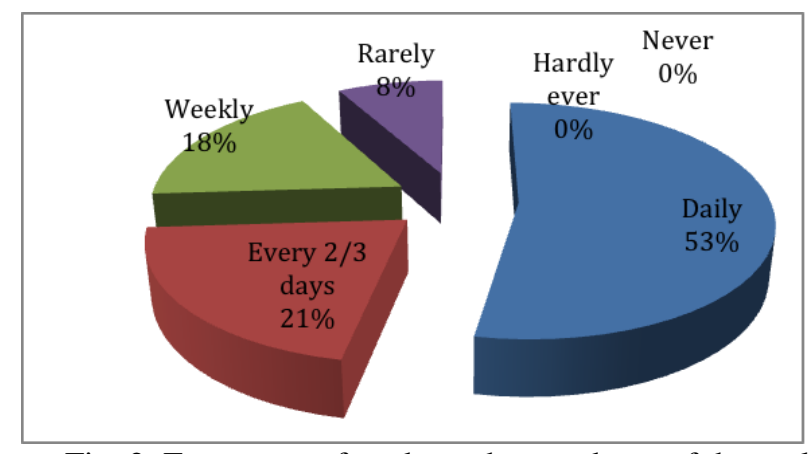

Fig. 2. Frequency of students that used one of the tools mentioned.
When interviewed ten students on the use of Web 2.0 tools in their learning of Microbiology, all ten students emphasized on the advantages of the application in collaborating and interacting with instructor and fellow friends. 


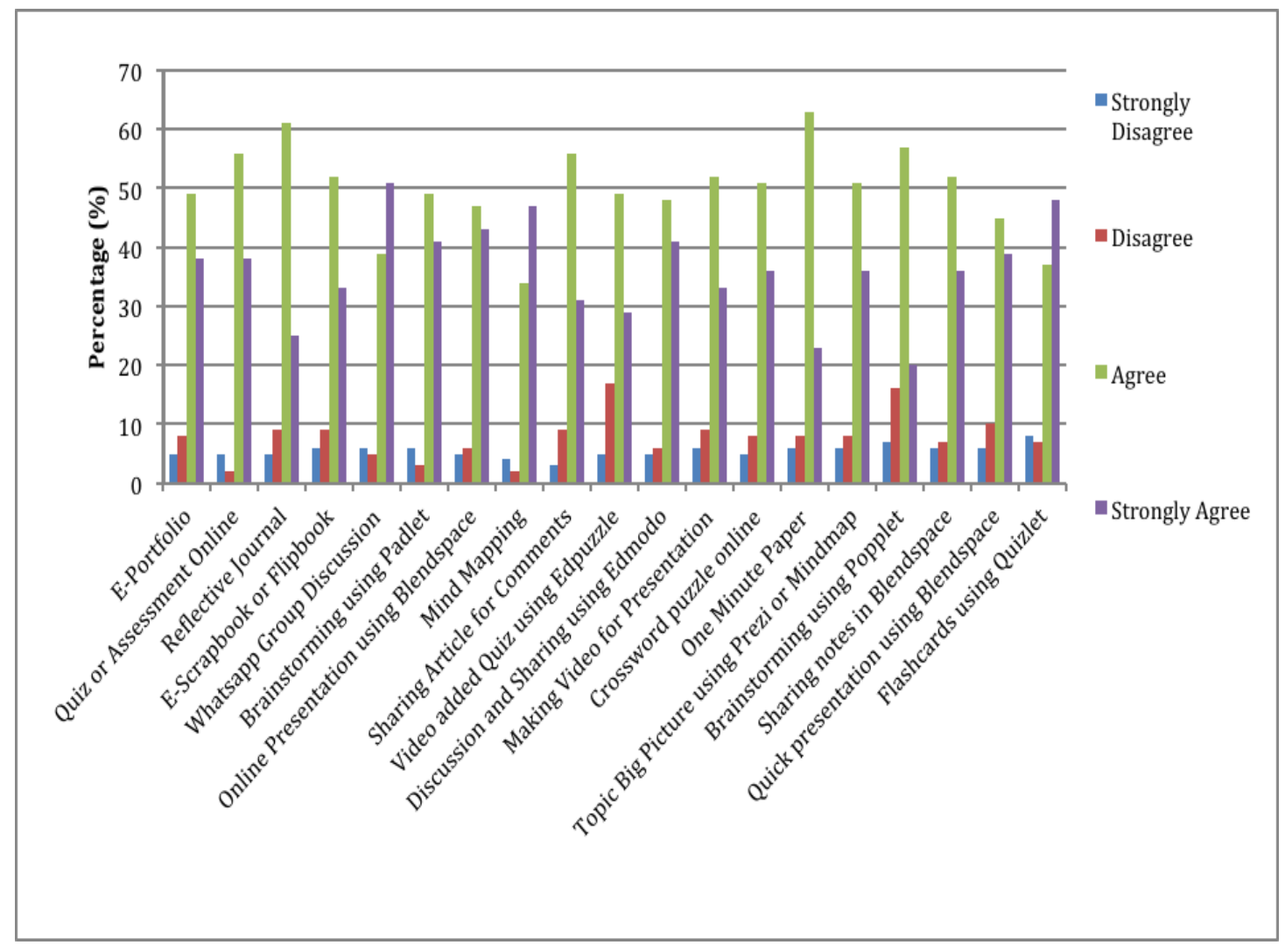

Fig. 3. E-learning activities that students thought had facilitated and enhanced their learning in Microbiology.

\section{Discussion}

Students who are more comfortable with technology in their everyday lives may more readily accept using technology in another context. Web 2.0 technologies are becoming popular in teaching and learning environments. Among them several online collaborative tools, like mindmap, wikis and blogs, have been integrated into educational settings. Collaborative tools can serve as a knowledge platform for a community of practice where members of the community can share their knowledge with the group, post information by sharing and comments on relevant articles, and critically discuss issues. The quality of learning depends on the depth of student engagement in the learning process. Student learning depends on the level and quality of their interaction with learning experiences.

From this study, it was found that a positive relationship between experiences and perceptions of using Web 2.0 tools as good evidence that the approach has benefited the students in enhancing their learning in Microbiology course.

\section{Acknowledgment}

The author would like to thank the students of Bachelor of Science (Hons.) in Microbiology of Faculty of
Biotechnology and Biomolecular Sciences, Universiti Putra Malaysia, Malaysia.

\section{References}

[1] G. Kennedy, K-L. Krause, K. Gray, K., T. Judd, S. Bennett, K. Maton, and et al., "Questioning the net generation: a collaborative project in Australian higher education," In Who's learning? Whose technology? Proceedings Ascilite Sydney 2006, L. Markauskaite, P. Goodyear \& P. Reimann (Eds.), pp. 413-417, 2006. Retrieved August 2014, from http://www.ascilite.org.au/conferences/sydney06/proceeding/pd f_papers/p160.pdf.

[2] G. Kennedy, K-L. Krause, A. Churchward, T. Judd, and K. Gray, "First year students' experiences with technology: are they really digital natives?," Internal report. The University of Melbourne, 2006. Retrieved August 2014, from http://www.bmu.unimelb.edu.au/research/munatives.

[3] R. B. Kvavik, "Convenience, communications, and control: How students use technology," In Educating the net generation, D. Oblinger \&J. Oblinger (Eds.), Boulder, CO: Boulder, 2005.

[4] G. Salaway, J. B. Caruso, and M. R, Nelson, "The ECAR study of undergraduate students and information technology," Research Study, vol. 8, 2008. Boulder, CO: EDUCAUSE. Center for Applied Research. Retrieved August 2014, from http://net.educause.edu/ir/library/pdf/ERS0808/RS/ERS0808w. pdf

[5] H. Green and C. Hannon, Their space: Education for a digital generation. London: Demos, 2007.

[6] C. Keller and L. Cernerud, "Students' perceptions of e-learning in university education," Journal of Educational Media, vol. 27, no. 1-2, pp. 55-67, 2007. 